\title{
A New Soybean Cultivar 'Jinyang': Yellow Soybean Cultivar with Lipoxygenase 1,2,3 Protein-free
}

\author{
Jong II Chung* \\ Department of Agronomy, Research Institute of Life Science, Gyeongsang National University, \\ Chinju 660-701, Korea
}

\begin{abstract}
Soybean is the main source of protein and oil for human and animal nutrition. However, antinutritional factors in the raw mature soybean are exist. Lipoxygenase protein is the main antinutritional factor in mature soybean seed. A new soybean cultivar, 'Jinyang' with yellow seed coat and free of lipoxygenase 1,2,3 protein was developed. It was selected from the population derived from the cross between 'Jinpumkong2ho' and GS301. 'Jinyang' has purple flowers, tawny pubescence, a determinate growth habit, oval leaflet shape, and light brown pods at maturity. The seed has yellow hilum and yellow seed coat color. Seed protein and oil content on a dry weight basis were $33.5 \%$ and $16.6 \%$, respectively. It has shown a resistant reaction to soybean necrosis, soybean mosaic virus, cercospora leaf spot and blight, black root rot, pod and stem blight, and soybean pod borer. 'Jinyang' matured in 1 October with plant height of $65 \mathrm{~cm}$ and a 100 -seed weight of $21 \mathrm{~g}$. Average yield of 'Jinyang' was $300-330 \mathrm{~kg} / 10 \mathrm{a}$ in 2010 - 2012. 'Jinyang' has been registered as a new soybean cultivar (registration number: 4279, registration date: Dec. 28, 2012) by Korea Seed \& Variety Service, Republic of Korea.
\end{abstract}

Keywords : Soybean, Jinyang, Lipoxygenase, Yellow seed, Good taste

\section{INTRODUCTION}

Soybean [Glycine $\max (\mathrm{L}$.) Merr.] is the main source of protein and oil for food and feed. Demand of soybean and soybean products has increased by high quantity and quality of soybean protein and oil. But antinutritional factors exist in the raw mature soybean. Lipoxygenase is the main antinutritional factor in mature soybean seeds. End-products of lipoxygenase activity are converted to many volatile compounds, which are responsible for the beany flavor associated with soybean products. Lipoxygenase proteins constitute about $1-2 \%$ of the protein in soybean seeds and can be isolated as three isoenzymatic forms. Lipoxygenase proteins are controlled by single dominant genes i.e. Lox1, Lox2 and Lox3, while absence is ascribed to corresponding recessive alleles (loxl, lox2, lox3). The studies on inheritance and genetic elimination of lipoxygenase protein were reported (Hildebrand \& Hymowitz 1981, Davies \& Nielsen 1986, Kitamura et al.

\footnotetext{
*Corresponding author (E-mail: jongil@gnu.ac.kr, Tel: +82-55772-1872, Fax: +82-55-772-1879)
}

(Received on May 13, 2014. Revised on July 30, 2014.

Accepted on September 11, 2014.)
1983). Genotypes with lipoxygenase free are better accepted due to production of very low levels of hexanal compounds (Kobayashi et al. 1995). Heat inactivation of the lipoxygenase at industrial level not only incurs extra cost but also affects the solubility and functionality of proteins (MacLeod \& Ames 1988). Development of genotypes with lipoxygenase free through genetic elimination is the key to get rid of the beany-flavour. So far, a few cultivars with lipoxygenase free have been developed (Chung 2009). The new cultivar with traits of yellow seed coat and free of lipoxygenase 1,2,3 protein was developed.

\section{MATERIALS AND METHODS}

Two parents were used to improve new strains with traits of yellow seed coat and free of lipoxygenase 1,2,3 protein. The Cultivar 'Jinpumkong2ho' used as female has traits of yellow seed coat, and free of lipoxygenase 1,2,3 protein. GS301 used as male parent has yellow seed coat and lipoxygenase protein-present. $F_{1}$ seeds from the cross were obtained and were planted at greenhouse in 2003. Presence or absence of 
lipoxygenase protein in each of the $\mathrm{F}_{2}$ seed was tested by SDS-PAGE protein analysis. And, $\mathrm{F}_{2}$ seeds were planted in May 2004. Single $F_{2}$ plants were harvested based on plant type, height, maturity. Single plants with acceptable agronomical traits such as flowering date, maturity date, growth habit, plant type, lodging, and seed quality were selected in 2004. Pedigree selection method was used through $F_{3}$ and $F_{6}$ generation to select plants with yellow seed coat and free of lipoxygenase 1,2,3 protein. Agronomic traits of selected lines were tested at $F_{7}$ and $F_{8}$ generation. Yield, protein and oil content, and reaction to soybean disease and insect resistance were tested in Korea Seed \& Variety Service. Selection procedures are shown in Fig. 1.

\section{RESULTS AND DISCUSSION}

\section{Agronomic performance}

Qualitative trait of 'Jinyang' are shown in Table 1. 'Jinyang' has purple flowers, tawny pubescence, a determinate growth habit, oval leaflet shape, and light brown pods at maturity. The seed has yellow hilum and yellow seed coat color. Cotyledon color of mature seed is yellow.

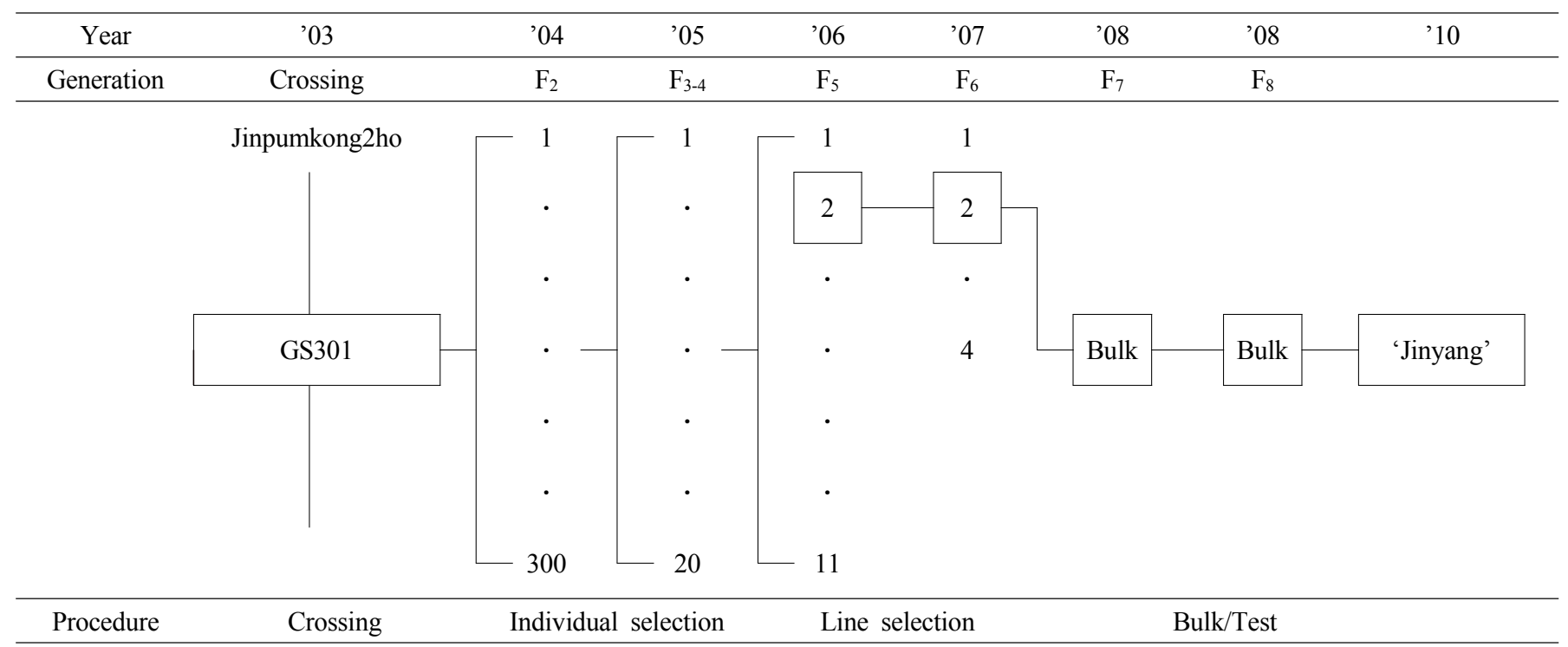

Fig. 1. Pedigree diagram of 'Jinyang' with the traits of yellow seed coat and free of lipoxygenase 1,2,3 protein.

Table 1. Qualitative traits of 'Jinyang' (New cultivar) and 'Taekwangkong' (Check cultivar).

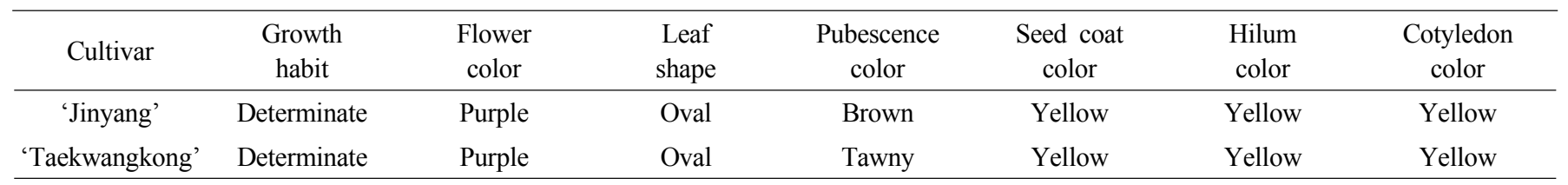

Table 2. Quantitative traits of 'Jinyang' (New cultivar) and 'Taekwangkong' (Check cultivar).

\begin{tabular}{cccccccc}
\hline \multirow{2}{*}{ Cultivar } & $\begin{array}{c}\text { Flowering } \\
\text { date }\end{array}$ & $\begin{array}{c}\text { Maturity } \\
\text { date }\end{array}$ & $\begin{array}{c}\text { Plant height } \\
(\mathrm{cm})\end{array}$ & $\begin{array}{c}\text { Lodging }^{\mathrm{z}} \\
(0-9)\end{array}$ & $\begin{array}{c}\text { 100-seed } \\
\text { weight }(\mathrm{g})\end{array}$ & $\begin{array}{c}\text { Shattering }^{\mathrm{y}} \\
(0-9)\end{array}$ & $\begin{array}{c}\text { Yield } \\
(\mathrm{Kg} / 10 \mathrm{a})\end{array}$ \\
\hline 'Jinyang' & July 15 & Oct. 2 & 65 & 1.0 & 21 & 4.0 & $300-330$ \\
'Taekwangkong' & July 20 & Oct.. 20 & 75 & 1.7 & 25 & 3.7 & $310-340$ \\
\hline
\end{tabular}

${ }^{\mathrm{z}} 0$ : not lodged, 9: completely lodged

${ }^{\mathrm{y}} 0$ : no shattering, 9 : completely shattering 
Quantative traits of 'Jinyang' are shown in Table 2. 'Jinyang' flowered in July 15, which is 5 days earlier than 'Taekwangkong'. 'Jinyang' matured in October 2, which is about 18 days earlier than 'Taekwangkong'. Plant height of 'Jinyang' was $65 \mathrm{~cm}$ compared to the check cultivar of $75 \mathrm{~cm}$. 'Jinyang' had a lodging score of 1.0 versus 'Taekwangkong' with a lodging score of 1.7. The 100-seed weight of 'Jinyang' (21g) was less than that of 'Taekwangkong' (25g). 'Jinyang' had a shattering score of 4.0 versus 'Taekwangkong' with a score of 3.7. Average Yield of 'Jinyang' was $300-330 \mathrm{~kg} / 10 \mathrm{a}$ in $2010-2012$.

Traits for seed components of 'Jinyang' are shown in Table 3. Average seed protein and oil content on a dry weight basis were $33.5 \%$ and $16.6 \%$, respectively compared to $36.8 \%$ and $19.5 \%$ of the check cultivar, 'Taekwangkong'. Lipoxygenase $1,2,3$ protein was absent in 'Jinyang', but was present in 'Taekwangkong'. Plants and seeds of 'Jinyang' are shown in Fig. 2.
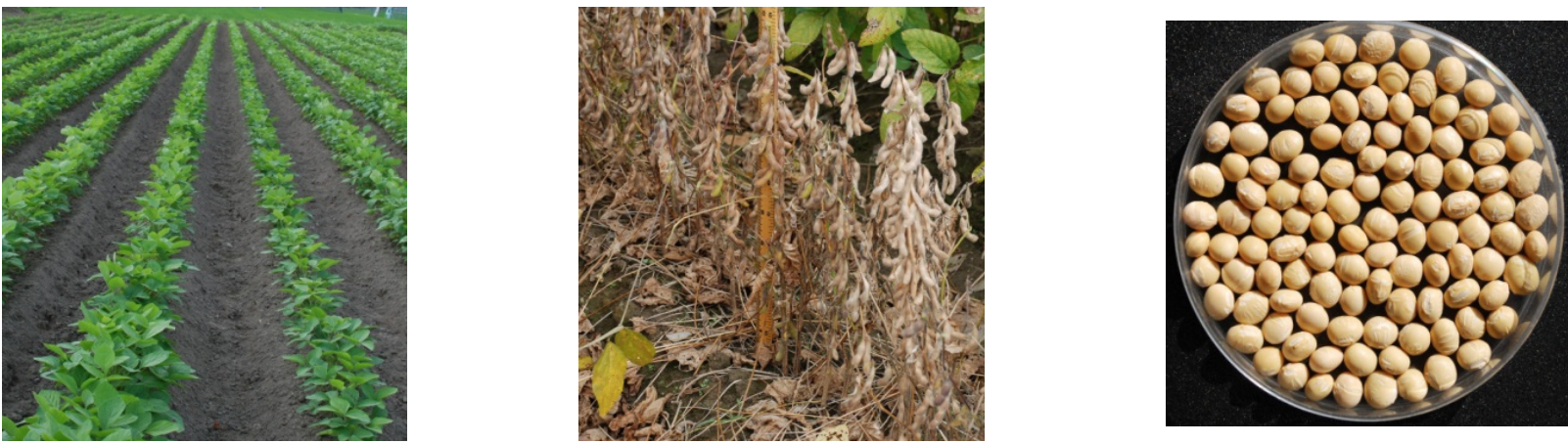

Fig. 2. Plant and seed of 'Jinyang'.

Table 3. Traits for seed components of 'Jinyang' (New cultivar) and 'Taekwangkong' (Check cultivar).

\begin{tabular}{cccc}
\hline Cultivar & Crude protein (\%) & Crude oil (\%) & Lipoxygenase protein \\
\hline 'Jinyang' & 33.5 & 16.6 & $1,2,3$-absent \\
'Taekwangkong' & 36.8 & 19.5 & $1,2,3$-present \\
\hline
\end{tabular}

Table 4. Resistant degree of 'Jinyang' (New cultivar) and 'Taekwangkong' (Check cultivar) to soybean disease and insect.

\begin{tabular}{ccccccc}
\hline Cultivar & $\begin{array}{c}\text { Necrosis } \\
(0-9)\end{array}$ & $\begin{array}{c}\text { Mosaic } \\
\text { virus } \\
(0-9)\end{array}$ & $\begin{array}{c}\text { Cercospora leaf } \\
\text { spot and blight } \\
(0-9)\end{array}$ & $\begin{array}{c}\text { Black } \\
\text { root rot } \\
(0-9)\end{array}$ & $\begin{array}{c}\text { Pod and } \\
\text { stem light } \\
(0-9)\end{array}$ & $\begin{array}{c}\text { Soybean } \\
\text { pod borer } \\
(0-9)\end{array}$ \\
\hline 'Jinyang' & 0.5 & 0.5 & 0 & 0 & 0 & 0.2 \\
'Taekwangkong' & 1.0 & 1.0 & 0 & 0 & 0 & 1.0 \\
\hline
\end{tabular}




\section{REFERENCES}

1. Chung JI. 2009. A new cultivar 'Gaechuck\#1': black soybean cultivar with lipoxygenase2,3-free, Kunitz trypsin inhibitorfree and green cotyledon. Korean J. Breed. Sci. 41: 603606.

2. Davies CS, Nielsen SS. 1986. Genetic analysis of a nullallele for lipoxygenase-2 in soybean. Crop Sci. 26: 460462 .
4. Hildebrand DF, Hymowitz T. 1981. Soybeans lacking lipoxygenase. J. Am. Oil Chem. Soc. 58: 583-586.

5. Kitamura K, Davies CS, Kaizuma N, Nielsen NC. 1983. Genetic analysis of a null-allele for lipoxygenase-3 in soybean seeds. Crop Sci. 58: 583-586.

6. Kobayashi AT, Hirata N, Kubota K, Kitamura. 1995. Aroma constituents of soybean milk lacking lipoxygenase isozymes. J. Agri. Food Chem. 43: 2449-2452.

7. MacLeod G, Ames J. 1988. Soya flavor and its improvement. CRC Crit. Rev. Food Sci. Nutr. 27: 219-400. 